\title{
INPP5D wt Allele
}

National Cancer Institute

\section{Source}

National Cancer Institute. INPP5D wt Allele. NCI Thesaurus. Code C95112.

Human INPP5D wild-type allele is located in the vicinity of 2q37.1 and is approximately $192 \mathrm{~kb}$ in length. This allele, which encodes phosphatidylinositol-3,4,5-trisphosphate 5phosphatase 1 protein, plays a role in the regulation of many signal transduction pathways. 